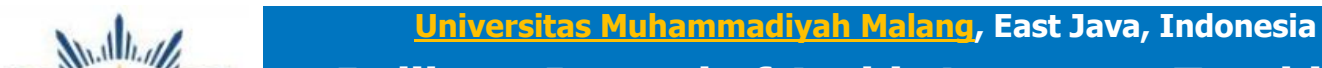 \\ Izdihar : Journal of Arabic Language Teaching, \\ Linguistics, and Literature \\ p-ISSN: 2622-738X, e-ISSN: 2622-7371 // Vol. 2 No. 3 December 2019, pp. 201-216 \\ do)
}

\section{Effectiveness of A/-Thariqah A/-Intiqaiyyah in Improving Arabic Learning Outcomes for Islamic Senior High School Students}

\author{
Miftachul Janaha, ${ }^{a}$, Afif Kholisun Nashoih ${ }^{b, 2}$ \\ a,bUniversitas KH. A. Wahab Hasbullah, Indonesia \\ ${ }^{1}$ miftachuljanah1224@gmail.com*, ${ }^{2}$ afif.nashoih90@gmail.com
}

\section{ARTICLE INFO}

\section{Article History:}

Received: 26/10/2019

Revised: $28 / 01 / 2020$

Accepted: 29/01/2020

Published: $30 / 01 / 2020$

\section{*Corresponding}

Author:

Name: Miftachul Janah

Email:

miftachuljanah1224@gmail.com

\section{Keyword}

\section{ABSTRACT}

This study aimed to determine the effectiveness of learning Arabic in improving learning outcomes by using Al-Thariqah Al-Intiqaiyyah in tenth class of science major at Islamic Senior High School 3 Jombang. This study used a quasi-experimental method with a non-equivalent control group pretest post-test design. The population in this study were all tenth classes of science major at Islamic Senior High School 3 Jombang while the sample was tenth class of science major 8 as a control class and tenth class of science major 6 as an experimental class. Data were analyzed descriptively and inferentially. From the test data, it can be seen that the average outcomes of the experimental class and the control class has increased. The average pre-test score of the control class was 55.25 and the average post-test score was 79.25 while the average pre-test score of the experimental class was 55.25 and the average post-test score was 87 . Based on the results of the SPSS 16.0 analysis, sig values were obtained. (2-tailed) of the experimental class and the control class posttest was 0.00 which means less than 0.05 . So it can be concluded that $H_{1}$ is accepted then there is a significant difference between the experimental class post-test and the control class post-test. $\mathrm{H}_{1}$ acceptance proves that $\mathrm{Al}$-Thariqah Al-Intiqaiyyah was effective in improving Arabic learning outcomes in tenth class of science major at Islamic Senior High School 3 Jombang. Copyright (c) 2019, Janah et al This is an open access article under the CC-BY-SA license

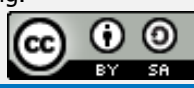

Al-Thariqah Al-Intiqaiyyah; Arabic Language; Effectiveness; Outcomes Learning

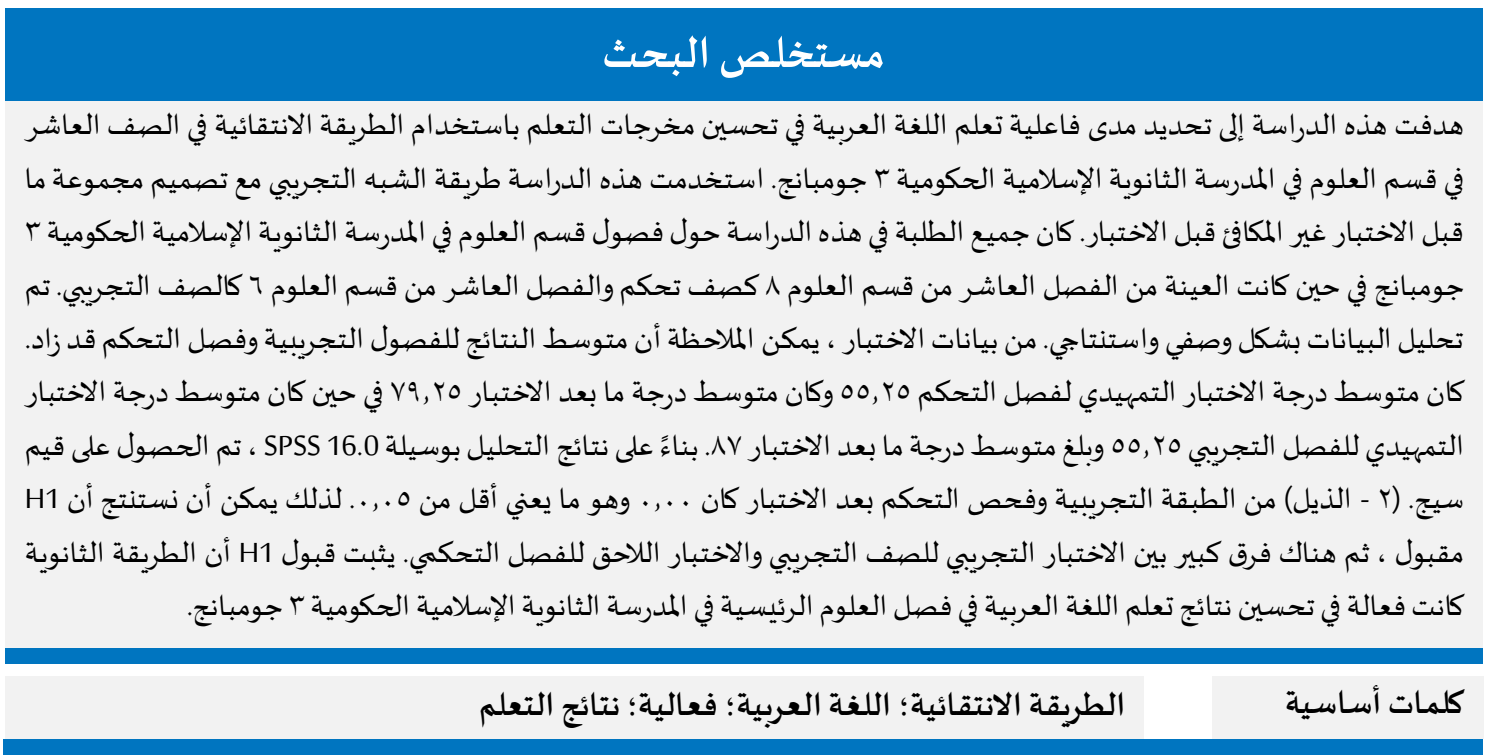




\section{INTRODUCTION}

At present Arabic is not only the language of communication used by the Arabs and beyond, but also the language of Muslims in Islamic countries (Ayatullah, 2016). Arabic is one of the world's languages spoken by more than $200,000,000$ people (Kusiyah, 2015). This language is the official language of approximately 22 countries in the world (Ridlo, 2015). This is because Arabic is the language of the Holy Qur'an (Nikmah, 2019, p. 79), Hadith and scientific sources which become guidelines and references for Muslims.(Buhori \& Wahidah, 2017) This language is very closely related to the religious life of Muslims wherever they are (Marlina, 2016).

Based on the regulation of the Minister of Religion of the Republic of Indonesia Number 2 of 2008 concerning graduate competency standards and content standards of Islamic religious education and Arabic language in Islamic schools in chapter VIII, Arabic subjects are subjects directed to encourage, guide, develop, and foster abilities as well foster a positive attitude towards Arabic both repressive and productive (Hakim, 2017). Repressive ability is the ability to understand the speech of others and understand reading texts. Productive ability is the ability to use language as a means of communication both verbally and in writing (Roviin, 2018). Therefore, Arabic is one of the subjects taught in schools today. Especially Islamic based schools such as Madrasah Ibtidaiyah (equivalent to Elementary Schools), Madrasah Tsanawiyah (equivalent to Middle Schools), and Madarasah Aliyah (equivalent to High Schools). Even in public schools and colleges, Arabic is one of the foreign languages used as an international language (Khoiriyah, 2012).

In the Arabic language learning there are four skills that must be mastered (Taufiq, 2018), i.e. listening skills (maharah istima), speaking skills (maharah kalam), reading skills (maharah qira'ah), and writing skills (maharah kitabah) (Awaluddin, 2018). For non-Arabs, appropriate methods and strategies are needed that can make it easier for students to understand and master all of these skills. Arabic language teaching and learning activities cannot be separated from the participation of teachers and students. Because the effectiveness of a learning activity is related to how far the learning plan is implemented or achieved. If there are ten types of activities planned by teachers and only five activities can be carried out, the effectiveness of these activities is still inadequate. Therefore, Arabic teachers must know various methods and strategies of learning Arabic well to have a good learning outcome. Learning outcomes are behavioral changes that occur after the teaching and learning process in accordance with educational objectives (Purwanto, 2010, p. 54; Sudjana, 2002, p. 22). There are two factors that influence learning outcomes, they are the factors of the students themselves and factors that come from outside the students (Sudjana, 2010, p. 39).

The learning method is one of the factors that play an important role in the teaching and learning process. The choice of the appropriate method by a 
teacher influences the success of learning. In choosing the appropriate method, it is necessary to consider certain principles including the advantages and disadvantages of the method itself. There are so many Arabic learning methods that can be used. Each method has its strengths and weaknesses. A method was born because of dissatisfaction with the previous method, but still found advantages and disadvantages of these methods (Rifa'i, 2015).

In Islamic Senior High School 3 Jombang, especially in Arabic subjects, the grammar and tarjamah, audiolingual, and qira'ah learning methods are often used. From the results of applying these methods, there are many lacks in learning that can be seen from students' interests and learning outcomes. The results of preliminary observations at Islamic Senior High School 3 Jombang in September 2019 still found a number of problems in learning Arabic. These problems include: (1) lack of variety of Arabic learning methods, (2) students feel afraid of speaking Arabic because they feel they do not master Arabic, (3) students' interest in Arabic is lacking, it can be seen from students' slow response in Arabic learning activity, (4) Arabic learning is mostly doing written exercises and Arabic grammar, (5) there are many students whose grades of Arabic are still below standard, (6) students' Arabic ability is uneven and many students do not master the four Arabic language skills, (7) some students who have difficulty in learning Arabic because of their educational background before. Therefore, from the problems above, a solution needed to overcome the lacks in learning.

One of the solutions to the learning problem is by using a different method from the previous method. In this study the authors offer an eclectic method ( $A$ /Thariqah Al-Intiqaiyyah) which is a combination of elements of several methods (Mustofa, 2017). The Eclectic Method has many names in Arabic, such as AlThariqah Al-Intiqaiyyah, Al-Thariqah Al-Khiyariyah, dan Al-Thariqah AlMukhtarah, Al-Thariqah At-Taufiqiyyah, Al-Thariqah Al-Muzdawij. Al-Thariqah AlIntiqaiyyah is a combination of several elements of the method, such as $A /$ Thariqah Al-Mubasyarah and Al-Thariqah Al-Qawaid Wa Tarjamah (Raswan, 2018). Then the teacher follows the following steps when teaching Arabic with this method: muhadatsah, kitabah, reading comprehension then reading the text. The activities consist of training syafawiyah, qira'ah jahriyah then continued with question and answer. The distinctive feature of this method is the use of practical methods in learning qawaid using audio-visual media (Mustofa \& Hamid, 2016). With Al-Thariqah Al-Intiqaiyyah method, educators do not focus on one method, but they have discretion. One of the reasons that underlies this method is there is no perfect method free from deficiencies. Each method has advantages and disadvantages. With this method, educators can take the positive side or the advantages of several methods and leave their shortcomings (Suja'i, 2010).

Eclectic means to choose from various sources (Echols \& Shadily, 1997, p. 35). Eclectic also means to choose from various sources of methods (Tim Penyusun Kamus Pembinaan dan Pengembangan Bahasa, 1999, p. 251). The eclectic method is a combination of various teaching methods and learning

Please cite this article as Janah, M. \& Nashoih, A. K. (2019). Effectiveness of Al-Thariqah Al-Intiqaiyyah in Improving Arabic Learning Outcomes for Islamic Senior High School Students. Izdihar : Journal of Arabic Language Teaching, Linguistics, and Literature, 2(3), 201-216. DOI: https://doi.org/10.22219/jiz.v2i3.10108 
approaches (Kumar, 2013). In addition, Gao described the eclectic method as not a single method, but a method that combines listening, speaking, reading and writing and includes several exercises in class. The current preferred teaching method is the integration of grammar translation, structural methods and advises teachers to take advantage of all other methods (Mwanza, 2017). In Arabic this method is called by several names, they are: al-thariqah al intiqaiyyah, althariqah al-muzdawwijah, al-thariqah al-mukhtarah, and al-thariqah altaufiqiyyah (Efendi, 2012, p. 69). Based on all of these notions, it can be understood that the eclectic method is a method that combines several methods that are considered most relevant to learning and classroom situations in order to achieve educational goals.

This method appears as a reaction to the previous methods. This method is based on several basic concepts, they are: (1) every method has advantages. This advantage can be used for learning Arabic. (2) there are no perfect and wrong methods. All methods have their positive and negative sides. (3) each method has different characteristics. If it is combined, it will become a complementary and perfect collaboration. (4) there is no method that suits the learning objectives, the characteristics of all students, all teachers, and all types of Arabic learning programs. (5) the most important point in the learning process is to be centered on students and their needs, not to master certain methods. (6) educators should feel free to choose the best method that suits the conditions of their students and is not fixed on the procedure of a particular method (Khuli, 2010, p. 27). As with other methods, Al-Thariqah Al-Intiqaiyyah also has advantages and disadvantages. The advantages are: (1) more varied activities, (2) students' abilities are more evenly distributed (Rahman, 2011, p. 71). The shortcomings of this method are (1) time allocation, willingness of educators and students to be well planned. (2) this method requires versatile educators. (3) it takes a long time compared to other methods (Muna, 2011, p. 100).

The use of eclectic methods in learning Arabic is fairly large. Most of the research is directed to find the effect of eclectic methods on learning. Such as research conducted by (Raswan, 2018) on the influence of eclectic learning methods on students' Arabic learning outcomes in 2018 and (Awaluddin, 2018) research on the effects of eclectic learning methods on students' Arabic learning outcomes in 2018. Similar research was also conducted by (Rifa'i, 2015) about the implementation of eclectic methods in learning Arabic in 2015. All three studies show that the use of eclectic methods provides great effectiveness in learning Arabic.

Based on the phenomenon above, researchers conducted the research that Al-Thariqah Al-Intiqaiyyah became a solution in overcoming the problems encountered in learning Arabic in MAN 3 Jombang. Therefore, this study aimed to determine the effectiveness of learning Arabic in an effort to improve learning outcomes in Arabic by using Al-Thariqah Al-Intiqaiyyah in tenth class of MIPA MAN 3 Jombang. 


\section{METHOD}

This study used a quantitative approach. The method used is a quasiexperiment method. Quasi experimental design is divided into two, namely time series design and nonequivalent control group design (Sugiyono, 2018, p. 73). In this study using the pretest posttest nonequivalent control group design. This design is almost the same as pre-test posttest one group design, the difference in this design control class and experimental class are chosen randomly (Fransiska \& Elmubarok, 2015).

Populations can be defined as individuals as a whole within the scope to be studied (Fauzi et al., 2019). The population in this study were 8 class $X$ science major at Islamic Senior High School 3 Jombang while the sample was $X$ science major 8 as a control class and $X$ science major 6 as an experimental class with 40 students each class. Data collection techniques using pretest and posttest. Furthermore, analyzing the pretest and posttest data using descriptive statistical data analysis and inferential statistics. Meanwhile, to test the research hypothesis using t-test. Before conducting the test, a data normality test and a data homogeneity test are performed. All tests can be done after determining the average, standard deviation and variance in each class.

\section{FINDINGS \& DISCUSSION}

\section{Descriptive Statistical Analysis Pre-test Experimental Class}

Based on the grade obtained from the pre-test results of class $X$ science major 6 as an experimental class, the average score of 40 students is 55.25 rounded to 55. The highest score is 90 and the lowest ones is 20. From the calculation results, the range obtained is 15 with the number of intervals is 5 .

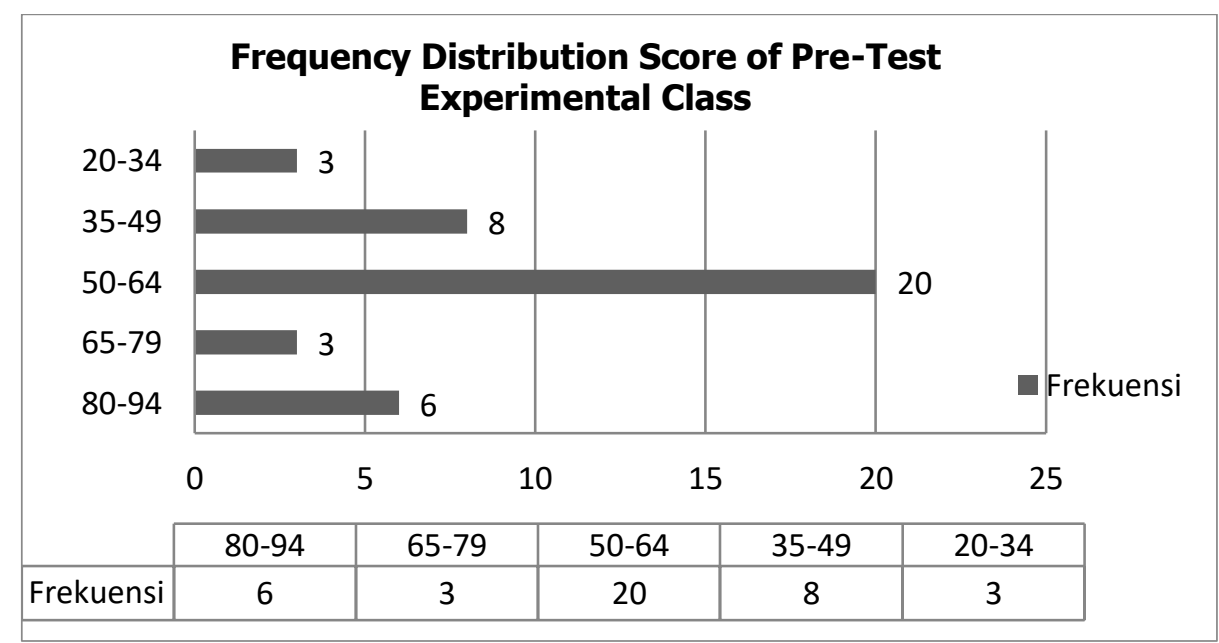

Figure 1. Frequency Distribution Score of Pre-Test Experimental Class 
The frequency data of the experimental class pretest scores based on the figure 1 shows that there were 6 out of 40 students (15\%) obtaining grades at the interval score with a range of $80-94$. Then 3 students (7.5\%) obtaining grades on the interval of scores with a range of $65-79.20$ students $(50 \%)$ obtained grades at the interval of scores with a range of 50-64. 8 students (20\%) obtained grades at intervals of scores with a range of $35-49.3$ students (7.5\%) obtained grades at intervals of scores with a range of 20-34. This proves that the level of Arabic language skills of experimental class students working on pre-test questions is low.

\section{The Pre-test of Control Class}

Based on the grade obtained from the pre-test results of class $X$ science major 8 as an control class, the average score of 40 students is 55.25 rounded to 55 . The highest score is 90 and the lowest ones is 20 . From the calculation results, the range obtained is 15 with the number of intervals is 5 .

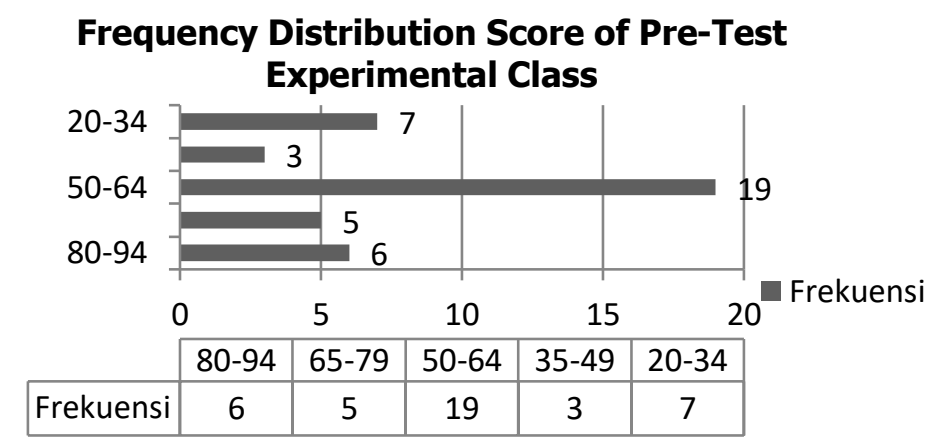

Figure 2. Frequency Distribution Score of Pre-Test Experimental Class

Frequency data and percentage of pre-test scores of the control class based on the figure 2 shows that there are 6 out of 40 students (15\%) obtaining grades at the interval of scores with a range of $80-94$. Then 5 students $(12.5 \%)$ obtained grades at the interval of scores with a range of 65-79. 19 students $(47.5 \%)$ obtained grades at the interval of scores with a range of 50-64. 3 students $(7.5 \%)$ obtained grades at intervals of scores with a range of 35-49. 7 students (17.5\%) obtained grades at intervals of scores with a range of 20-34. This proves that the level of Arabic language skills of control class students in working on pre-test questions is low. After the $\mathrm{X}$ science major 6 class or the experimental class were treated with the Al-Thariqah al-Intiqaiyyah method, they were given a post test to see the level of Arabic language skills. Likewise, students of class $\mathrm{X}$ science major 8 as the control class, they were given a post test at the end of the meeting class to find out the extent of the Arabic ability without being treated. 


\section{The experimental class' post test}

Based on the grades obtained from the post test results of students of class X science major 6 as an experimental class, the mean of 40 students is 87. The highest score is 100 and the lowest ones is 60 . From the calculation results obtained a range of 10 with a number of score intervals are 5 .

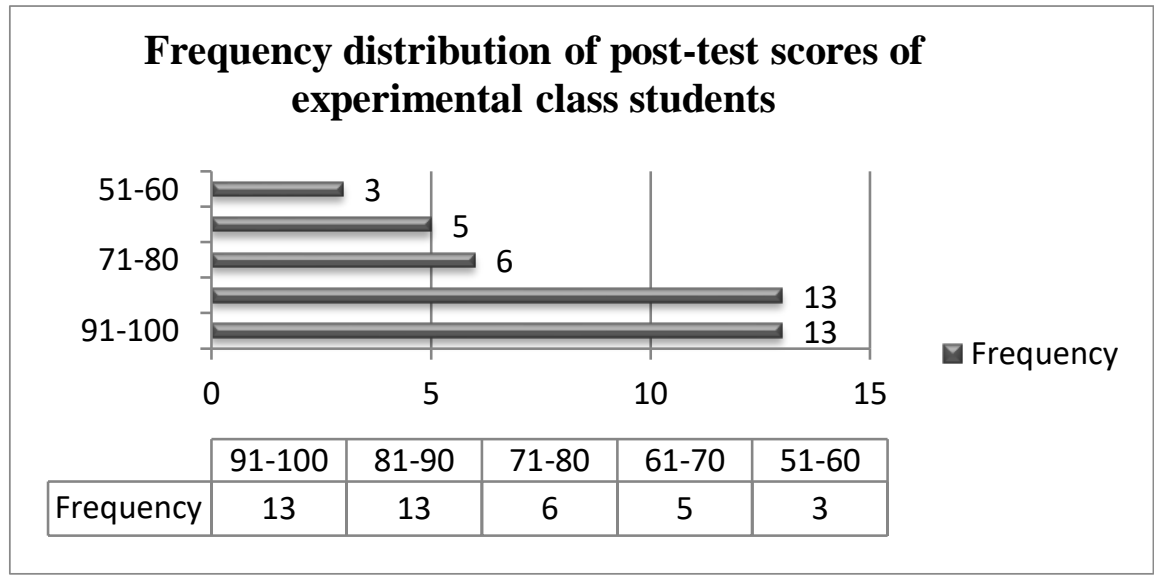

Figure 3. Frequency distribution of posttest grades of experimental class students

The frequency data of the experimental class post-test scores based on the figure 3 shows that there were 13 out of 40 students (32.5\%) obtaining grades at the interval score with a range of 91-100. Then 13 students (32.5\%) obtained grades at intervals of scores with a range of 81-90. 6 students $(15 \%)$ scored on the interval of scores with a range of 71-80. 5 students $(12.5 \%)$ obtained grades at the interval score with a range of $61-70.3$ students $(7.5 \%)$ obtained grades at the interval of scores with a range of 51-60. This proves that the level of Arabic language skills of experimental class students in working on post test questions is very good.

\section{The Post Test of Control Class}

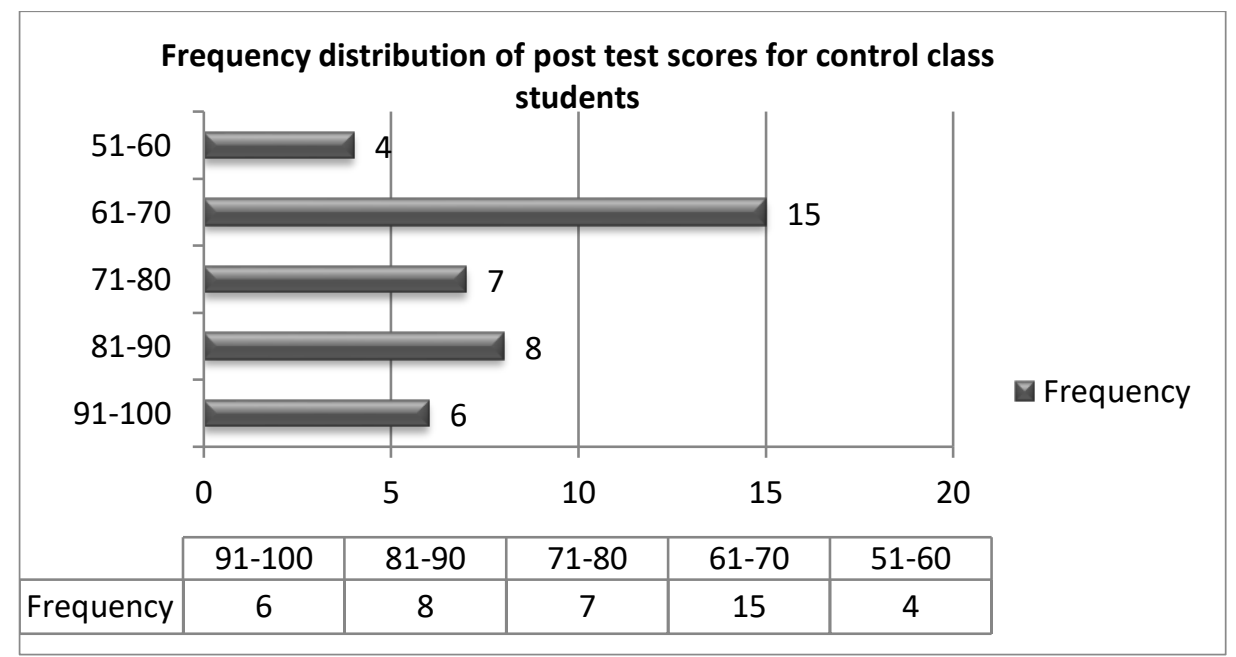

Figure 4. Frequency distribution of post test scores for control class students

Please cite this article as Janah, M. \& Nashoih, A. K. (2019). Effectiveness of Al-Thariqah Al-Intiqaiyyah in Improving Arabic Learning Outcomes for Islamic Senior High School Students. Izdihar : Journal of Arabic Language Teaching, Linguistics, and Literature, 2(3), 201-216. DOI: https://doi.org/10.22219/jiz.v2i3.10108 
Based on the grades obtained from the post test results of students of class X science major 8 as a control class, the grades mean of 40 students is 79.25 rounded to 79 . The highest score is 100 and the lowest one is 60 . From the calculation results obtained a range of 10 with a number of score intervals are 5 .

The frequency and percentage data of the control class post-test scores based on the figure 4 shows that there were 6 out of 40 students $(15 \%)$ who obtained grades at the interval of scores with a range of 91-100. Then 8 students (20\%) obtained grades at intervals of scores with a range of 81-90. 7 students $(17.5 \%)$ scored on the interval of scores with a range of 71-80. 15 students $(37.5 \%)$ scored on the interval score with a range of $61-70.4$ students $(10 \%)$ obtained scores at the interval of scores with a range of 51-60. This proves that the level of Arabic language skills of control class students in working on post test questions is very good.

\section{Inferential Statistical Analysis Test data normality}

Table 1. Test the pretest normality of the experimental class Tests of Normality

\begin{tabular}{|l|r|r|r|}
\hline \multirow{2}{*}{} & \multicolumn{3}{|c|}{ Shapiro-Wilk } \\
\cline { 2 - 4 } & Statistic & \multicolumn{1}{c|}{ df } & \multicolumn{1}{c|}{ Sig. } \\
\hline The Experimental Class & .941 & 40 & .067 \\
\hline
\end{tabular}

A data in table 1 is said to be normally distributed if the value of sig.> 0.05 and not normally distributed if the value of sig. $<0.05$. Based on the table above, the value of sig. in the experimental class is 0.067 , which means greater than 0.05 . Then the pretest scores of the experimental class are normally distributed or according to students' abilities.

Table 2. Test the pretest normality of the control class

\begin{tabular}{|l|r|r|c|}
\hline \multirow{2}{*}{} & \multicolumn{3}{|c|}{ Shapiro-Wilk } \\
\cline { 2 - 4 } & Statistic & Df & \multicolumn{1}{c|}{ Sig. } \\
\hline The Control Class & .956 & 40 & .118 \\
\hline
\end{tabular}

Based on the table 2, the value of sig. in the control class is 0.118 , which means greater than 0.05 . Then the control class pre-test scores are normally distributed or according to students' abilities. 


\section{Homogeneity Test}

Table 3. Pre-test homogeneity tests of experimental and control classes Test of Homogeneity of Variances

\begin{tabular}{|l|r|r|r|r|}
\hline & \multicolumn{1}{|c|}{$\begin{array}{l}\text { Levene } \\
\text { Statistic }\end{array}$} & \multicolumn{1}{c|}{ df1 } & \multicolumn{1}{c|}{ df2 } & \multicolumn{1}{c|}{ Sig. } \\
\hline Pre-test & .234 & 1 & 48 & .631 \\
\hline
\end{tabular}

A data in table 3 is said to be homogeneous if the value of sig.> 0.05 and not homogeneous if the value of sig. $<0.05$. Based on the data above, it can be concluded the pre-test sample both the experimental class and the control class have the same or homogeneous variants because of the sig value. is 0.631 which means it is greater than 0.05 .

\section{Hypothesis test}

\section{Experimental class (pre-test post-test)}

To determine the level of difference in the ability of Arabic experimental class (X science major 6 , then the hypothesis test with SPSS 16.0 is as follows:

Table 4. Independent samples test test of the experimental class Independent Samples Test

\begin{tabular}{|c|c|c|c|c|c|c|c|c|c|}
\hline & \multicolumn{2}{|c|}{$\begin{array}{c}\text { Levene's Test } \\
\text { for Equality } \\
\text { of Variances }\end{array}$} & \multicolumn{7}{|c|}{ t-test for Equality of Means } \\
\hline & \multirow[b]{2}{*}{$\mathrm{F}$} & \multirow[b]{2}{*}{ Sig. } & \multirow[b]{2}{*}{$\mathrm{T}$} & \multirow[b]{2}{*}{ df } & \multirow{2}{*}{$\begin{array}{l}\text { Sig. (2- } \\
\text { tailed) }\end{array}$} & \multirow{2}{*}{$\begin{array}{c}\text { Mean } \\
\text { Difference }\end{array}$} & \multirow{2}{*}{$\begin{array}{l}\text { Std. Error } \\
\text { Difference }\end{array}$} & \multicolumn{2}{|c|}{$\begin{array}{l}\text { 95\% Confidence } \\
\text { Interval of the } \\
\text { Difference }\end{array}$} \\
\hline & & & & & & & & Lower & Upper \\
\hline $\begin{array}{l}\text { Equal } \\
\text { variances } \\
\text { assumed }\end{array}$ & $\begin{array}{r}2.20 \\
0\end{array}$ & .142 & 9.551 & 78 & .000 & 31.75000 & 3.32411 & 25.13221 & $38.3677 \mathrm{c}$ \\
\hline $\begin{array}{l}\text { Equal } \\
\text { variances not } \\
\text { assumed }\end{array}$ & & & 9.551 & 72.479 & .000 & 31.75000 & 3.32411 & 25.12426 & 38.3757 \\
\hline
\end{tabular}

With the following testing criteria:

$\mathrm{H}_{0}=\mu_{1}=\mu_{2}$ Vs $\mathrm{H}_{1}=\mu_{1} \neq \mu_{2}$

$\mathrm{H}_{0}=$ there is no significant difference between pre-test and post-test

$\mathrm{H}_{1}=$ there is a significant difference between pre-test and post-test

$\mathrm{H}_{0}$ accepted if the value of sig. (2-tailed) $>0.05$, while $\mathrm{H}_{0}$ is rejected if sig. (2tailed) $<0.05$ (Latuconsina, 2018). 
Based on the table 4, the value of sig. (2-tailed) of the pre-test and posttest experimental class was $0.142>$ sig. 0.05 so it can be concluded that $\mathrm{H}_{0}$ is rejected, then there is a significant difference between pre-test and post-test experimental class.

\section{The control class (pre-test post-test)}

To find out the level of difference in Arabic language skills of the control class X science major 8 , a hypothesis test with SPSS 16.0 is performed as follows:

Table 5. Independent samples test of control class

Independent Samples Test

\begin{tabular}{|c|c|c|c|c|c|c|c|c|c|}
\hline & \multicolumn{2}{|c|}{$\begin{array}{l}\text { Levene's Test } \\
\text { for Equality } \\
\text { of Variances }\end{array}$} & \multicolumn{7}{|c|}{ t-test for Equality of Means } \\
\hline & \multirow[b]{2}{*}{$\mathrm{F}$} & \multirow[b]{2}{*}{ Sig. } & \multirow[b]{2}{*}{$\mathrm{T}$} & \multirow[b]{2}{*}{ Df } & \multirow{2}{*}{$\begin{array}{l}\text { Sig. } \\
(2- \\
\text { tailed) }\end{array}$} & \multirow{2}{*}{$\begin{array}{c}\text { Mean } \\
\text { Difference }\end{array}$} & \multirow{2}{*}{$\begin{array}{l}\text { Std. Error } \\
\text { Difference }\end{array}$} & \multicolumn{2}{|c|}{$\begin{array}{l}95 \% \text { Confidence } \\
\text { Interval of the } \\
\text { Difference }\end{array}$} \\
\hline & & & & & & & & Lower & Upper \\
\hline $\begin{array}{l}\text { Equal variances } \\
\text { assumed }\end{array}$ & 3.254 & .075 & -6.965 & 78 & .000 & -24.00000 & 3.44601 & -30.86048 & -17.13952 \\
\hline $\begin{array}{l}\text { Equal variances } \\
\text { not assumed }\end{array}$ & & & -6.965 & 70.883 & .000 & -24.00000 & 3.44601 & -30.87135 & -17.12865 \\
\hline
\end{tabular}

Based on the table 5, the value of sig. (2-tailed) of the pre-test and posttest control classes was $0.00<$ sig. 0.05 so it can be concluded that $\mathrm{H}_{0}$ is rejected then there is a significant difference between pre-test and post-test control class.

\section{Post-test (control class and experimental class)}

Table 6. Independent samples test post-test experimental class and control class

\section{Independent Samples Test}

\begin{tabular}{|c|c|c|c|c|c|c|c|c|c|}
\hline & \multicolumn{2}{|c|}{$\begin{array}{l}\text { Levene's Test } \\
\text { for Equality } \\
\text { of Variances }\end{array}$} & \multicolumn{7}{|c|}{ t-test for Equality of Means } \\
\hline & \multirow[b]{2}{*}{$\mathrm{F}$} & \multirow[b]{2}{*}{ Sig. } & \multirow[b]{2}{*}{$\mathrm{T}$} & \multirow[b]{2}{*}{ Df } & \multirow{2}{*}{$\begin{array}{l}\text { Sig. (2- } \\
\text { tailed) }\end{array}$} & \multirow{2}{*}{$\begin{array}{c}\text { Mean } \\
\text { Difference }\end{array}$} & \multirow{2}{*}{$\begin{array}{l}\text { Std. Error } \\
\text { Difference }\end{array}$} & \multicolumn{2}{|c|}{$\begin{array}{l}95 \% \text { Confidence } \\
\text { Interval of the } \\
\text { Difference }\end{array}$} \\
\hline & & & & & & & & Lower & Upper \\
\hline $\begin{array}{ll}\text { Posttes } & \text { Equal } \\
\text { t } & \text { variances } \\
\text { assumed } \\
\text { Equal } \\
\text { variances } \\
\text { not } \\
\text { assumed }\end{array}$ & $\begin{array}{r}.06 \\
5\end{array}$ & .799 & $\begin{array}{l}-2.730 \\
-2.730\end{array}$ & 77.996 & .008 & -7.75000 & 2.83833 & -13.40067 & -2.09933 \\
\hline
\end{tabular}


Based on the table 6, the value of sig. (2-tailed) of the control class and experimental class post-test was $0.008<$ sig. 0.05 so it can be concluded that $\mathrm{H}_{0}$ is rejected, then there is a significant difference between the experimental class post-test and the control class. Thus, $\mathrm{H}_{0}$ which reads: there is no significant difference in Arabic learning outcomes of students who are taught using AlThariqah al-Intiqaiyyah and students who are not taught by using $A$-Thariqah alIntiqaiyyah are rejected. The consequence of rejecting $\mathrm{H}_{0}$ is $\mathrm{H}_{1}$ which reads: there is a significant difference in the learning outcomes of Arabic students who are taught using $A$-Thariqah al-Intiqaiyyah and students who are not taught by using $A$-Thariqah al-Intiqaiyyah are accepted. $\mathrm{H}_{1}$ acceptance proves that $A /$ Thariqah al-Intiqaiyyahis effective in improving the learning outcomes of Arabic class X science major at Islamic Senior High School 3 Jombang.

Learning in this study was conducted during six meetings including pretest and post-test. In the learning process, both classes are taught with different methods. In the experimental class, students are taught with Al-Thariqah alIntiqaiyyahwhile the control class is not taught with At-Tariqah Al-Intiqaiyyah.

The pre-test results showed that the mean value for the experimental class was 55.25 and the control class was 55.25 in learning Arabic in class X science major at Islamic Senior High School 3 Jombang. The total number of pre-test scores for the experimental class is 2210 and the control class is 2210. The normality test results in the pre-test data in both classes indicate that the pretest value of the experimental class has a sig value. 0.067 , which means $>$ sig. 0.05 , then the pre-test grades of the experimental class are normally distributed, meaning that the tests are given according to students' abilities.

Based on the results of the experimental class post-test, the use of $\mathrm{Al}$ Thariqah al-Intiqaiyyah has a positive impact on improving students' Arabic learning outcomes. This can be seen from the acquisition of students' post-test scores, in the experimental class the lowest score is 60 and the highest one is 100 with an average score of 87 , while in the control class the lowest score is 60 and the highest one is 100 with an average score of 79.25. More than that, the learning outcomes of the experimental class Arabic completed in the pre-test were obtained by 9 students (22.5\%). After being given treatment, students who completed the post-test were 38 students $(95 \%)$, the percentage was more increased (72.5). From this it follows that Al-Thariqah al-Intiqaiyyahis quite helpful in improving students' Arabic learning outcomes.

In the normality test data of the control class pre-test, the pre-test value of class X science major 8 has sig. 0.071 which means $>$ sig. 0.05 then the pretest value of the control class is normally distributed. This indicates that the test given is in accordance with the ability of students. While the normality test data of the experimental class pre-test, the pre-test value of class $X$ science major 6 has sig. 0.067, which means > sig. 0.05, then the pre-test value of the experimental class is normally distributed. This indicates that the test given is in accordance with the ability of students. The next test is the homogeneity test. 
This test is to find out whether the control class and the experimental class have the same variant so that the data can be said to be homogeneous. In the table. 3 shows that the pre-test of both samples both the experimental class and the control class have the same or homogeneous variants because of the sig value. is 0.631 which means greater than 0.05 .

The results of the analysis above are followed by t-test to see the final results of this study. Based on table 6 above the value of sig. (2-tailed) of the experimental class post-test and the control class post-test is 0.008 which means less than 0.05 so it can be concluded that $\mathrm{H}_{0}$ is rejected, so there is a significant difference between the experimental class post-test and the post-test class control.

$\mathrm{H}_{0}$ was resulted: there is no significant difference in Arabic learning outcomes of students who are taught using Al-Thariqah al-Intiqaiyyah and students who are not taught by using Al-Thariqah al-Intiqaiyyah are rejected. The consequence of rejecting $\mathrm{H}_{0}$ is $\mathrm{H}_{1}$ which reads: there is a significant difference in the learning outcomes of Arabic students who are taught using A/Thariqah al-Intiqaiyyah and students who are not taught by using $A$-Thariqah alIntiqaiyyah are accepted. Thus it can be concluded that the use of Al-Thariqah al-Intiqaiyyahin learning Arabic is effective. this proves that the learning outcomes of the experimental class Arabic are very good by being treated using Al-Thariqah al-Intiqaiyyah. after being treated there were significant differences between the pre-test and post-test experimental classes.

The results demonstrated in this chapter match state of the arts methods. Here is the comparation for the results of the proposed method with those of the same methods and researches with differences in samples of the research and level of school grades. Raswan, (2018, pp. 137-138) had resulted that every method has advantage and disadvantage and there is no best method in teaching process. Al-Thariqah al-Intiqaiyyah is perfect for previous methods of teaching such as grammar translation method and others. Awaluddin (2018, p. 165) had resulted the same with the research of Raswan but his sample of research focused in implementing Al-Thariqah al-Intiqaiyyah for Islamic junior high school. Rifa'i (2015, p. 172) also did the same research but he focused in qualitative descriptive for the implementation of Al-Thariqah al-Intiqaiyyah. He found two fundamental problems for Arabic teaching in MTsN 1 Kediri. He also offered A/Thariqah al-Intiqaiyyah (all in one system) method to solve the problems.

\section{CONCLUSIONS}

As stated in the introduction that this research is used to find out the effectiveness of $A$-Thariqah al-Intiqaiyyah as an effort to improve the learning outcomes of Islamic Senior High School 3 Jombang students on Arabic subjects. 
Researchers realize that al-Thariqah al-Intiqaiyyah is not a new method. It's just that, as a solution to overcome problems in learning Arabic, the method needs to be used, bearing in mind that quite a lot of research uses Al-Thariqah alIntiqaiyyah or eclectic methods to be able to overcome problems in learning.

This research has implication that the learning outcomes of students taught using Al-Thariqah al-Intiqaiyyah are higher than students who are not treated. It was reflected in the learning outcomes of experimental class students who had a mean of 87 , and the learning outcomes of control class students who had a mean of 79.25. In addition, the results of the T-test also stated that there were significant differences between the learning outcomes of the experimental class and the control class. It means that the use of al-Thariqah al-Intiqaiyyah is effective in improving Arabic learning outcomes of students of tenth class of science major at Islamic Senior High School 3 Jombang.

\section{قائمة المراجع / BIBILIOGRAPHY}

Awaluddin, A. F. (2018). Pengaruh Pembelajaran Metode Eklektik terhadap Hasil Belalajar Bahasa Arab Siswa Madrasah Ma'had Hadits Al-Junaidiyah Biru Bone. Didaktika: Jurnal Kependidikan, 12(2), 151-167.

Ayatullah, A. (2016). Penerapan Metode Eklektik pada Pembelajaran Bahasa Arab Siswa Kelas VI SDIT Anak Sholeh Mataram. Palapa, 4(1), 149-167. DOI: https://doi.org/10.36088/palapa.v4i1.75

Buhori, B., \& Wahidah, B. (2017). Bahasa Arab dan Peradaban Islam: Telaah atas Sejarah Perkembangan Bahasa Arab dalam Lintas Sejarah Peradaban Islam. Jurnal Al-Hikmah: Jurnal Dakwah, 11(1). DOI: https://doi.org/10.24260/al-hikmah.v11i1.822

Echols, J., \& Shadily, H. (1997). Kamus Inggris Indonsia (p. 35). Jakarta: Gramedia Pustaka Utama.

Efendi, A. F. (2012). Metodologi Pengajaran Bahasa Arab. Malang: Misykat.

Fauzi, M. F., Buhun, M. F., \& Purwadi, A. (2019). The Influence of Teams Games Tournament (TGT) toward Students' Interest in Arabic Language Learning. Izdihar: Journal of Arabic Language Teaching, Linguistics, and Literature, 2(2), 135-148. DOI: https://doi.org/10.22219/jiz.v2i2.9986 
Fransiska, F., \& Elmubarok, Z. (2015). Efektivitas Metode Reading Guide Terhadap Keterampilan Membaca Bahasa Arab Siswa Kelas XI IPS MAN Demak. 4(1), 56-60. DOI: https://doi.org/10.15294/la.v4i1.7634

Hakim, M. L. (2017). Pemanfaatan Media Pembelajaran Game Interaktif dalam Pembelajaran Kosakata Bahasa Arab. Arabi: Journal of Arabic Studies, 2(2), 156-162. DOI: http://dx.doi.org/10.24865/ajas.v2i2.56

Khoiriyah, R. L. (2012). Pengaruh Metode Eklektik terhadap Hasil Belajar Keterampilan Berbicara Bahasa Arab Siswa Kelas X MA Manahijul Huda Ngagel Dukuhseti Pati. Lisanul' Arab: Journal of Arabic Learning and Teaching, 1(1). DOI: https://doi.org/10.15294/la.v1i1.1509

Khuli, M. A. (2010). Strategi Pembelajaran Bahasa Arab. Yogyakarta: Basan Publishing.

Kumar, C. P. (2013). The Eclectic Method-Theory and Its Application to the Learning of English/IJSRP February 2013 Publication. 3(6). http://www.ijsrp.org/research-paper-0613.php?rp=P181291

Kusiyah, T. (2015). Penggunaan Metode Eklektik dalam Pembelajaran Mufradat di Madrasah Ibtidaiyah Darul Hikmah Bantarsoka Purwokerto Barat Tahun Pelajaran 2014/2015. IAIN Purwokerto: Unpublished Undergraduate Thesis.

Latuconsina, S. N. (2018). Efektivitas Permainan Bahasa Arab dalam Meningkatkan Kemampuan Membaca Mahasiswa Program Studi Pendidikan Bahasa Arab. Arabi: Journal of Arabic Studies, 3(2), 145-156. DOI: http://dx.doi.org/10.24865/ajas.v3i2.99

Marlina, L. (2016). Efektifitas Metode Langsung Dalam Pengajaran Keterampilan Berbicara Bahasa Arab. Al-Tsaqafa: Jurnal Ilmiah Peradaban Islam, 13(02), 211-226. DOI: https://doi.org/10.15575/al-tsaqafa.v13i02.1973

Muna, W. (2011). Metodologi Pembelajaran Bahasa Arab. Yogyakarta: Teras.

Mustofa, B., \& Hamid, A. (2016). Metode dan Strategi Pembelajaran Bahasa Arab. Malang: UIN Malik Press.

Mustofa, S. (2017). Strategi Pembelajaran Bahasa Arab Inovatif. Malang: UIN Maliki Press. 
Mwanza, D. S. (2017). The Eclectic Approach to Language Teaching: Its Conceptualization and Misconceptions. International Journal of Humanities Social Sciences and Education (IJHSSE), 4(2) 53-67. DOI: http://dx.doi.org/10.20431/2349-0381.0402006

Nikmah, K. (2019). Meaning Variations of Qala (قال) in Indonesian Language. Izdihar: Journal Of Arabic Language Teaching, Linguistics, and Literature, 2(2), 77-100. DOI: https://doi.org/10.15408/bat.v25i1.11506

Purwanto. (2010). Evaluasi Hasil Belajar. Yogyakarta: Pustaka Pelajar.

Rahman, A. A. (2011). Pengajaran Bahasa Arab dengan Metode Eklektik. Jurnal Adabiyah, 11(1), 65-74.

Raswan, R. (2018). Pengaruh Metode Pembelajaran Eklektik Terhadap Hasil Belajar Bahasa Arab Siswa. Arabiyat: Jurnal Pendidikan Bahasa Arab Dan Kebahasaaraban, $5(1)$, 121-140.

DOI: https://doi.org/10.15408/a.v5i1.7007

Ridlo, U. (2015). Bahasa Arab Dalam Pusaran Arus Globalisasi: Antara Pesismisme Dan Optimisme. Ihya Al-Arabiyah: Jurnal Pendidikan Bahasa Dan Sastra Arab, 1(2). 210-226

Rifa'i, A. (2015). Implementasi Thariqah Al Intiqaiyyah (Metode Eklektik) pada Pembelajaran Bahasa Arab di MTsN Kediri 1. Realita: Jurnal Penelitian Dan Kebudayaan Islam, 13(2). DOI: https://doi.org/10.30762/realita.v13i2.60

Roviin. (2018). Pengembangan Kurikulum Bahasa Arab di Madrasah. Tarling: Journal of Language Education, 1(2), 1-18. DOI: https://doi.org/10.24090/tarling.v1i2.1248

Sugiyono. (2018). Metode Penelitian Kuantitatif, Kualitatif, dan R\&D. Bandung: Alfabeta.

Suja'i. (2010). Inovasi Pembelajaran Bahasa Arab. Semarang: Walisongo Press.

Sudjana, N. (2002). Penilaian Hasil Proses Belajar Mengajar. Bandung: Remaja Rosdakarya.

Sudjana, N. (2010). Dasar-Dasar Proses Belajar Mengajar. Bandung: Sinar Baru Algensindo. 
Taufiq, A. (2018). Dafi'iyyah Istikhdam al-Ta'allum al-Ta'awuny li Tanmiyah Ta'lim Maharah al-Kalam. Izdihar: Journal of Arabic Language Teaching, Linguistics, and Literature, 1(1). 79-104. DOI: https://doi.org/10.22219/izdihar.v1i1.6564

Tim Penyusun Kamus Pembinaan dan Pengembangan Bahasa. (1999). Kamus Besar Bahasa Indonesia. Jakarta: Balai Pustaka. 